\title{
CORRELATION BETWEEN DIETING PATTERNS WITH TOTAL CHOLESTEROL LEVELS IN BLOOD IN THE HKBP CHURCH CON- GREGATION ON SEPTEMBER 2018
}

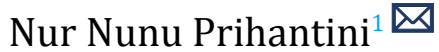 \\ ${ }^{1}$ Medical Faculty, Universitas Kristen, Jakarta, Indonesia
}
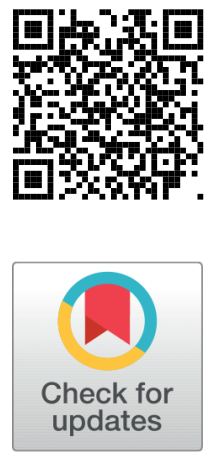

Received 6 April 2021

Accepted 21 April 2021

Published 30 April 2021

Corresponding Author

Nur Nunu Prihantini, nur.nunu@u

ki.ac.id

DOI 10.29121/

granthaalayah.v9.i4.2021.3864

Funding: This research received no specific grant from any funding agency in the public, commercial, or not-for-profit sectors.

Copyright: (C) 2021 The Author(s). This is an open access article distributed under the terms of the Creative Commons Attribution License, which permits unrestricted use, distribution, and reproduction in any medium, provided the original author and source are credited.

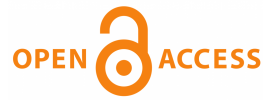

\section{ABSTRACT}

Serum total cholesterol levels above $200 \mathrm{mg} / \mathrm{dL}$ (Hypercholesterolemia) have repeatedly been correlated with cardiovascular and other degenerative diseases. Many risk factors can lead to Hypercholesterolemia, one of which is the dietary pattern. A dietary pattern is one simple way to start, which can be modified to avoid Hypercholesterolemia. This study describes the correlation between dietary pattern with serum total cholesterol levels within HKBP Sudirman church congregation in September 2018 using a cross-sectional study, and the sample was obtained from accidental sampling. Therefore, there is no requirement for both inclusion and exclusion criteria. In total, 38 respondents contributed to this research. Data retrieval was done using questionnaires for the dietary pattern and rapid test for the serum total cholesterol levels. The data was used to analyze by the Pearson Chi-Square test. Based on the study result, there was a significant relationship between carbohydrate consumption frequency with the respondents' serum total cholesterol levels $(p=0,031)$. In contrast, the significant relationship between protein consumption frequency $(p=0,631)$, fat consumption frequency $(p=0150)$, fiber consumption frequency $(p=0,631)$ and fast-food consumption frequency $(p=$ 0,150 ) with serum total cholesterol levels of the respondents were not found.

Keywords: Dietary Pattern, Serum Total Cholesterol Levels

\section{INTRODUCTION}

Health is a significant thing for improving quality and extending human life expectancy. Awareness of the importance of maintaining health usually arises when a person experiences certain disease. Maintaining a regular and balanced diet is a simple step to keep the body healthy in everyday life. Of course, the proper diet will also provide maximum benefits for the body Cahanar and Suhanda (2006).Recently, the influence of globalization that has developed dynamically has made it easy to 
obtain delicious, cheap and easy to obtain food. Foods like this that are high in cholesterol, carbohydrates and salt can lead to Hypercholesterolemia and even obesity.Hypercholesterolemia is a condition where total cholesterol is found in the blood of more than or equal to $200 \mathrm{mg} / \mathrm{dL}$. According to the National Heart, Lung and Blood Institute, several factors that can affect total cholesterol levels are divided into two main factors, including modifiable factors, namely, diet, weight gain, physical activity, smoking habits, and non-modifiable factors namely, age, gender and heredity "US Department of Health and Human Services" (2005).

Based on research conducted by Vristilia et al. (2012) found that a diet high in saturated fatty acids from meat, egg yolks, dairy products, coconut oil, and margarine can increase cholesterol levels Malik (2011). However, cholesterol levels can be lowered by consuming fibrous foods that are generally derived from plants (dietary fibre) Fairudz (2015). Total cholesterol levels that exceed typical values can trigger various degenerative diseases which are generally influenced by age, such as heart disease, stroke, and diabetes mellitus Yoeantafara and Martini (2017).The highest global prevalence of Hypercholesterolemia was found in Europe (54\%), followed by America (48\%), Southeast Asia (29\%) and Africa (22.6\%) Ri (2013). Meanwhile, in Indonesia, the prevalence of Hypercholesterolemia is common in the age range of 2564 years, with the percentage of the 25-34 year age group being 9.3\% and increasing to $15.5 \%$ in the $53-64$ year age group, and is more common in women. that is, $2.2 \%$ compared to $1.5 \%$ of men in Indonesia. According to Riskesdas 2013, Hypercholesterolemia reached $39.6 \%$ in women, while in men, it was 30\%. The habit of eating fatty, cholesterol, and fried foods $\geq 1$ time/day based on data from the 2013 Basic Health Research (Riskesdas) survey in Indonesia is still relatively high, namely 40.7\% Ri (2013).

If not controlled, the World Health Organizations estimates that high total cholesterol levels can cause 2.6 million deaths and 29.7 million disability-adjusted life years (DALYs) worldwide. Early and routine preventive action, awareness and discipline in implementing healthy eating habits are needed Cummins et al. (2014). Therefore, the authors are interested in conducting a study entitled "Correlation between Diet and Blood Total Cholesterol Levels in HKBP Church Congregation, which are on Jenderal Sudirman Jakarta Street in September 2018". The problem that will be answered in this research is whether there is a correlation between diet and total cholesterol levels in the blood in Jemat at HKBP Church Jalan Jend. Sudirman Jakarta? The study's aim, namely "to determine the correlation between diet and total cholesterol levels in the blood in the HKBP Church Jalan Jend. Sudirman Jakarta".

\section{LITERATURE REVIEW}

Dietary consumption patterns are defined by the Ministry of Health of the Republic of Indonesia as the composition of foods commonly eaten, including the types and amounts of food consumed by a person or group of people/population within 
a particular frequency and period Indrati and Gardjito (2014). Ideal nutrition is obtained when the food consumed by the body every day provides a source of energy and nutrients that are in line with what humans need based on age, height and weight, type of activity, as well as body physiological conditions (illness, pregnancy, or breastfeeding) Murray et al. (2003). Of course, excess nutrients in the long term impact excess energy so that energy is stored in the form of fat tissue in the body and harms health.

Dietary modification to reduce cholesterol levels is recommended to reduce saturated fat intake by keeping fat levels below 30\% of total calories and saturated fat below $10 \%$. By lowering the amount of cholesterol in the diet, plasma cholesterol levels in humans, in general, can decrease by about $0.13 \mathrm{mmol} / \mathrm{L}$ serum cholesterol if avoiding foods with a cholesterol content of $100 \mathrm{mg}$ Supariasa et al. (2012).Assessment of nutritional status can be carried out in two ways, namely directly and indirectly. Direct assessment of nutritional status includes: anthropometric, clinical, biochemical and biophysical. Meanwhile, nutritional status assessment indirectly includes food consumption surveys, vital statistics, and ecological factors. Assessment of nutritional status using a food consumption survey is intended to determine eating habits and describe the adequacy of foodstuffs and nutrients that affect a person's food consumption. Food consumption surveys can be carried out in 3 ways, namely qualitative methods, quantitative methods and mixed methods (qualitative and quantitative).

Cholesterol is an amphipathic lipid based on steroid chemicals that are found in animals, is a significant component of membrane structures and a complex component of the outer layer of blood plasma lipoproteins, as well as a precursor to corticosteroids, sex hormones, bile acids and vitamin D. However, cholesterol is also found in a small amount on the membrane of the intracellular organelles Garrett and Grisham (2010); Sjöberg (2016).

In humans, cholesterol comes from two sources: food and synthesis in almost all cells with a nucleus Ali (2006); Supariasa et al. (2012). The body needs about $1100 \mathrm{mg}$ of cholesterol every day, synthesizes about $700 \mathrm{mg}$ of cholesterol/day and is obtained from food intake Rastogi et al. (2008). Generally, cholesterol is found in animal products because these compounds are produced from animal metabolic processes. Foods such as egg yolks, meat, liver, and animal brains contain cholesterol. In the body, cholesterol is found in tissues and blood plasma as free cholesterol or deposits. Cholesterol in the form of deposits will bind to long-chain fatty acids known as ester-cholesterol. In plasma, free cholesterol and ester cholesterol will be transported to tissues and organs in the body via lipoproteins.

Low-density lipoproteins (LDL), commonly referred to as bad cholesterol, will bind to free or stored cholesterol and function in transporting cholesterol and cholesterol-esters to many tissues. Meanwhile, high-density lipoproteins (HDL) or commonly referred to as good cholesterol, only bind to free cholesterol and function in removing it from the tissue and bringing it to the liver to be eliminated from the 
body as a form of unesterified cholesterol or as a result of its metabolism namely bile acids Supariasa et al. (2012).

Cholesterol consists of methyl group at positions 10 and 13, as well as an 8-to 10carbon alkyl side chain at position 17 , which is oriented towards the steroid nucleus (Beta-orientation), and the lengthening of the alkyl group from the back of the steroid is oriented towards Alpha-orientation, polyphenol on the side chain, oxygen in the C3 bond, either the hydroxyl group in sterols or the carbonyl group on other steroids. The cholesterol ring is relatively rigid, and the C-3 position, a weak polar alcohol group, is characteristic of the cholesterol plasma membrane Sjöberg (2016). Cholesterol in the body is synthesized by a precursor that comes from calories produced by carbohydrates, fats, and proteins, namely Acetyl-CoA. Therefore, the calorie intake from these three types of food ingredients also produces cholesterol in the body.

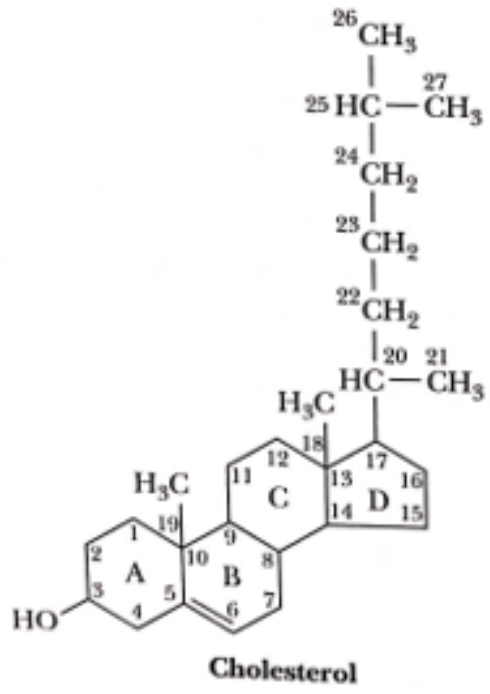

Figure 1 Cholesterol Structure [Garrett and Grisham (2010)]

The biosynthesis process of cholesterol occurs intracytoplasmic and consists of 5 main stages, namely: a) Synthesis of Mevalonate from Acetyl-CoA; b) Formation of the Isoprenoid Unit from Mevalonate through the release of $\mathrm{CO} 2$; c) Condensation of six Isoprenoid Units for the formation of Squalene; d) Squalene cyclization to produce lanosterol (parent steroid) and e) Cholesterol is formed from lanosterol Fatmah and Skm (2010); Supariasa et al. (2012).

Cholesterol ester is a storage form of cholesterol transported by LDL with the most significant proportion in plasma. Cholesterol ester derived from food will be hydrolyzed into cholesterol that is then absorbed by the proximal small intestine and unesterified cholesterol and other lipids in food, then put into chylomicrons to be carried to the Endoplasmic Reticulum and undergo esterification. According to Beatrice, about 300-500mg of dietary cholesterol and 600-1000mg of biliary cholesterol are absorbed per day. $80-90 \%$ of the cholesterol that has been esterified by AcetylKoA 
Acetyltransferase 2 (ACAT2) with long-chain fatty acids will be channelled to the liver chylomicron remnants (chylomicron remnants) and will be secreted by the liver in the form of VLDL during the formation. IDL, then LDL absorption occurs by LDL receptors in the liver and extrahepatic tissue. Although several studies suggest that HDL also contributes to the absorption of cholesterol and phospholipids Ali (2006); Poggio et al. (2017). Cholesterol is excreted mainly through the intrahepatic elimination pathway. In small amounts, the body also excretes it by excretion of steroid hormones in urine and sequestration of dead skin cells Supariasa et al. (2012).

The National Heart, Lung and Blood Institute divide several factors that can affect total cholesterol levels into two main factors: modifiable and non-modifiable factors. Modifiable factors consist of diet, weight gain, physical activity, and smoking habits. Meanwhile, factors that cannot be modified consist of heredity (genetics), age, and gender "US Department of Health and Human Services" (2005).

Based on the definition of Hypercholesterolemia, total cholesterol levels can be categorized as follows:

\begin{tabular}{|cc|}
$\begin{array}{l}\text { Table } 1 \\
\text { based on Hypercholesterolemia }\end{array}$ \\
Total Cholesterol Levels \\
\hline \multicolumn{3}{|c|}{ Total Cholesterol Levels } & Category \\
$\leq 200 \mathrm{mg} / \mathrm{dL}$ & Normal \\
$>200 \mathrm{mg} / \mathrm{dL}$ & High \\
\hline
\end{tabular}

Researchers in the data processing process use this category.

\section{RESEARCH METHODS}

This study used an analytic survey research design with a cross-sectional approach. This research was conducted on September 22 2018, at the HKBP Sudirman Church. This study's population were congregants of the HKBP Sudirman Church aged $\geq 40$ years who came at the research time. The number of respondents taken in this study was not planned and did not use formulas, but based on accidental sampling techniques, so that the number of research respondents was 36 people in the HKBP Sudirman Church. This research was conducted by taking primary data directly from the elderly congregation of the HKBP Sudirman Church, which included: the identity of the respondent (name, age, gender), the quality and quantity of food consumption, and the total blood cholesterol level of the respondent. The instruments used to collect data in this study included: a) 1-month eating habits questionnaire (dietary history); b) Qualitative food frequency questionnaire; c) EasyTouch brand total cholesterol measuring device; d) Cholesterol strips; e) Pen lancet; f) Lancet; and g) Alcohol swab. All data obtained in this study were processed in the SPSS version 23.0 computer program with the following stages: a) Editing b) Coding; c) Data Entry; d) Tabulating. 


\section{RESULT AND DISCUSSION}

In implementing the research carried out on September 22 2018, 38 respondents were willing to undergo the research procedure. The identity of the respondents is filled in according to age and gender.

\begin{tabular}{|c|c|c|}
\hline $\begin{array}{l}\text { Table } 2 \\
\text { tion of } \\
\text { dentsbase } \\
\text { Gender }\end{array}$ & & $\begin{array}{l}\text { ribu- } \\
\text { pon- } \\
\text { on }\end{array}$ \\
\hline Gender & $\mathbf{N}$ & $\%$ \\
\hline Female & 29 & 76,3 \\
\hline Male & 9 & 23,7 \\
\hline Total & 38 & 100 \\
\hline
\end{tabular}

Based on table 2, it can be seen that the respondents are primarily women, as many as 29 people (76.3\%), and the number of male respondents is nine people.

\begin{tabular}{lll}
\multicolumn{2}{l}{$\begin{array}{l}\text { Table } 3 \\
\text { ofRespondents by }\end{array}$} & \multicolumn{2}{c}{ Distribution } \\
\hline Age & N & $\%$ \\
\hline < 40 year & 3 & 7,9 \\
\hline 40-50 year & 10 & 26,3 \\
\hline 51-60 year & 10 & 26,3 \\
\hline 61-70 year & 6 & 15,8 \\
\hline 71-80 year & 6 & 15,8 \\
\hline 81-90 year & 3 & 7,9 \\
\hline Total & $\mathbf{3 8}$ & 100 \\
\hline
\end{tabular}

Based on table 3 above, the age of the youngest respondent is $<40$ years old, and the oldest respondent is 83 years old, where the most respondents who participated in the study came from the age range of 40-50 years and the age range of 51-60 years, as many as ten people (26.3\%). While the minor age group obtained from the age group $<40$ years and the age group 81-90 years, as many as three people (7.9\%). The two groups are aged 61-70 years and 71-80 years, and each contributed as many as six respondents.

Table 4 presents an overview of the types and frequencies of food consumed frequently and rarely by respondents. Based on the table above, it can be seen that all respondents, namely 38 people (100\%), consume rice every month as a source of carbohydrates. Apart from rice, bread is also a foodstuff from a carbohydrate source consumed by many respondents per day, namely 12 people (31.6\%). Cassava, sweet potatoes, noodles, and sweet drinks are types of food ingredients rarely consumed by respondents, of whom only one person (2.6\%) often consumes cassava and sweet potatoes per day. Two people (5.3\%) consume more noodles of or equal to $1 \mathrm{x} / \mathrm{day}$, and sweet drinks consumed by three people (7.9\%) per day from all respondents. 


\begin{tabular}{|c|c|c|c|c|c|c|c|c|c|c|}
\hline \multirow{3}{*}{$\begin{array}{c}\text { Types of Food } \\
\text { Ingredients }\end{array}$} & \multicolumn{8}{|c|}{ Food Frequency } & \multicolumn{2}{|c|}{ Total } \\
\hline & \multicolumn{2}{|c|}{$\underset{\text { day }}{\geq 1 x /}$} & \multicolumn{2}{|c|}{4 - 6x/week } & \multicolumn{2}{|c|}{$\begin{array}{c}1- \\
3 x / \text { week }\end{array}$} & \multicolumn{2}{|c|}{ Never } & \multirow[b]{2}{*}{$\mathbf{N}$} & \multirow[b]{2}{*}{$\%$} \\
\hline & $\mathbf{N}$ & $\%$ & $\mathbf{N}$ & $\%$ & $\mathbf{N}$ & $\%$ & $\mathbf{N}$ & $\%$ & & \\
\hline \multicolumn{11}{|l|}{$\begin{array}{c}\text { Sources of } \\
\text { Carbohydrates: }\end{array}$} \\
\hline - Rice & 20 & 52,6 & 17 & 44,7 & 1 & 2,6 & 0 & 0 & 38 & 100 \\
\hline - Cassava & 1 & 2,6 & 5 & 13,2 & 25 & 65,8 & 7 & 18,4 & 38 & 100 \\
\hline - Sweet potato & 1 & 2,6 & 3 & 7,9 & 27 & 71,1 & 7 & 18,4 & 38 & 100 \\
\hline - Bread & 12 & 31,6 & 8 & 21,1 & 16 & 42,1 & 2 & 5,3 & 38 & 100 \\
\hline - Noodles & 2 & 5,3 & 6 & 15,8 & 28 & 73,7 & 2 & 5,3 & 38 & 100 \\
\hline - Sweet drink & 3 & 7,9 & 13 & 34,2 & 20 & 52,6 & 2 & 5,3 & 38 & 100 \\
\hline \multicolumn{11}{|l|}{ Protein Source: } \\
\hline - Beef & 2 & 5,3 & 5 & 13,2 & 26 & 68,4 & 5 & 13,2 & 38 & 100 \\
\hline - Chicken meat & 12 & 31,6 & 3 & 7,9 & 21 & 55,3 & 2 & 5,3 & 38 & 100 \\
\hline - Lamb & 0 & 0 & 0 & 0 & 17 & 44,7 & 21 & 55,3 & 38 & 100 \\
\hline - Chicken eggs & 9 & 23,7 & 10 & 26,3 & 18 & 47,4 & 1 & 2,6 & 38 & 100 \\
\hline - Fish & 14 & 36,8 & 15 & 39,5 & 9 & 23,7 & 0 & 0 & 38 & 100 \\
\hline - Tempe/Tofu & 14 & 36,8 & 16 & 42,1 & 8 & 21,1 & 0 & 0 & 38 & 100 \\
\hline - Nuts & 2 & 5,3 & 12 & 31,6 & 21 & 55,3 & 3 & 7,9 & 38 & 100 \\
\hline \multicolumn{11}{|l|}{ Source of Fat: } \\
\hline - Milk & 9 & 23,7 & 6 & 15,8 & 13 & 34,2 & 10 & 26,3 & 38 & 100 \\
\hline - Vegetable oil & 4 & 10,5 & 4 & 10,5 & 24 & 63,2 & 6 & 15,8 & 38 & 100 \\
\hline - Offal & 1 & 2,6 & 0 & 0 & 14 & 36,8 & 23 & 60,5 & 38 & 100 \\
\hline - Cheese & 2 & 5,3 & 3 & 7,9 & 22 & 57,9 & 11 & 28,9 & 38 & 100 \\
\hline - Butter & 2 & 5,3 & 3 & 7,9 & 26 & 68,4 & 7 & 18,4 & 38 & 100 \\
\hline - Coconut milk & 1 & 2,6 & 2 & 5,3 & 29 & 76,3 & 6 & 15,8 & 38 & 100 \\
\hline \multicolumn{11}{|l|}{ Fast Food: } \\
\hline - Fast food & 0 & 0 & 3 & 7,9 & 24 & 63,2 & 11 & 28,9 & 38 & 100 \\
\hline - Soft drink & 0 & 0 & 3 & 7,9 & 18 & 47,4 & 17 & 44,7 & 38 & 100 \\
\hline • Fry & 4 & 10,5 & 8 & 21,1 & 19 & 50,0 & 7 & 18,4 & 38 & 100 \\
\hline \multicolumn{11}{|l|}{ Source of Fiber: } \\
\hline - Vegetables & 20 & 52,6 & 16 & 42,1 & 2 & 5,3 & 0 & 0 & 38 & 100 \\
\hline - Fruit & 18 & 47,4 & 14 & 36,8 & 6 & 15,8 & 0 & 0 & 38 & 100 \\
\hline
\end{tabular}

For protein sources, most often consumed by respondents are fish, tofu and tempeh, with the number of respondents as many as 14 people (36.8\%) who eat this type of food $\geq 1 \mathrm{x} /$ day. Chicken meat is also a type of food included in the category of frequently consumed by respondents, 12 people (31.6\%) consumed chicken meat, followed by chicken eggs consumed by nine people $(23.7 \%) \geq 1$ time/day. Beans and beef are only consumed by two people (5.3\%) per day. Most of the respondents, namely 12 people (31.6\%) and 21 people (55.3\%), do not consume nuts as a staple food, with the frequency of consumption. 4-6x/week and 1-3x/week. Meanwhile, the protein source that respondents rarely consumed was goat meat, with a frequency 
of 1-3 times/week as many as 17 people (44.7\%) and never as many as 21 people (55.3\%).

In the type of fatty food ingredients, milk is the source of fat most consumed by respondents per day, with nine people (23.7\%), followed by four people $(10.5 \%)$ adding vegetable oil to their food consumption per day. Offal, cheese, coconut milk and butter are the types of food items that are the least consumed by respondents, and this is stated by only one person (2.6\%) consuming offal and coconut milk every day, followed by cheese and butter, which only two people consume ( $5.3 \%$ ) per day.

For fast food consumption, it can be seen that most respondents tend to prefer fried food. It is stated by the frequency of fried food consumption which is included in the never category, is seven people (18.4\%), less than 11 people (11). 28.9\%) and soft drinks as many as 17 people (44.7\%).

All respondents consume vegetables and fruit every month; this is indicated by the absence of respondents who have never eaten vegetables and fruit. However, the frequency of consumption of vegetables and fruit for each respondent was found to vary. Most of the respondents often eat vegetables and fruit, with 20 people $(52.6 \%)$ eating vegetables and 18 (47.4\%) people eating fruit every day.

\begin{tabular}{ccc}
\hline $\begin{array}{l}\text { Table } 5 \\
\text { Frequency Distribution of } \\
\text { Respondentsbased on the Hyperc- } \\
\text { holesterolemia Classification }\end{array}$ & \\
\hline Total Cholesterol Levels & N & $\%$ \\
\hline Normal ( $200 \mathrm{mg} / \mathrm{dL})$ & 33 & 86,8 \\
\hline High $(>200 \mathrm{mg} / \mathrm{dL})$ & 5 & 13,2 \\
\hline
\end{tabular}

Based on table 5, it is found that the proportion of respondents who have normal total cholesterol levels is 33 people (86.8\%), more than five people who have high total cholesterol levels (13.2\%). It shows that of the entire population of respondents, the number of respondents who fall into high total cholesterol levels (>200mg/dL), namely five people, have Hypercholesterolemia.

According to data from 38 research respondents, the lowest total cholesterol level was $116 \mathrm{mg} / \mathrm{dL}$, and the highest was $342 \mathrm{mg} / \mathrm{dL}$. The total cholesterol average value was $168.7 \mathrm{mg} / \mathrm{dL}$ from the overall respondent data.

Based on table 6, it can be seen that the relationship between the frequency and type of diet and the total cholesterol level of the respondents using the Pearson ChiSquare test. According to the Pearson Chi-Square test results for the relationship between the frequency of carbohydrate consumption and total cholesterol levels, the value of $p=0.031(p<0.05)$ indicates a significant relationship between the frequency of carbohydrate consumption and the total cholesterol level of the respondents. Meanwhile, the Pearson Chi-Square test for the relationship between the frequency of protein consumption and total cholesterol levels obtained a value of $p$ $=0.631(\mathrm{p}>0.05)$, thus indicating no significant relationship between protein frequency consumption and the total cholesterol level of the respondents. The Pearson 
Table 6 Relationship between Typesand Frequency of Food and Total Cholesterol Levels of Respondents

\begin{tabular}{|c|c|c|c|}
\hline \multirow[t]{2}{*}{ Consumption } & \multicolumn{2}{|c|}{ Total Cholesterol Levels } & \multirow[t]{2}{*}{$\mathbf{P}$} \\
\hline & Normal & High & \\
\hline \multicolumn{4}{|c|}{ Consume Carbohydrates } \\
\hline Rarely & 17 & 0 & 0,031 \\
\hline Often & 16 & 5 & \\
\hline Total & 33 & 5 & 38 \\
\hline \multicolumn{4}{|l|}{ Consume Protein } \\
\hline Rarely & 17 & 2 & 0,631 \\
\hline Often & 16 & 3 & \\
\hline Total & 33 & 5 & 38 \\
\hline \multicolumn{4}{|l|}{ Consume Fat } \\
\hline Rarely & 18 & 1 & 0,150 \\
\hline Often & 15 & 4 & \\
\hline Total & 33 & 5 & 38 \\
\hline \multicolumn{4}{|l|}{ Consume Fiber } \\
\hline Rarely & 16 & 3 & 0,631 \\
\hline Often & 17 & 2 & \\
\hline Total & 33 & 5 & 38 \\
\hline \multicolumn{4}{|l|}{ Fast food } \\
\hline Rarely & 18 & 1 & 0,150 \\
\hline Often & 15 & 4 & \\
\hline Total & 33 & 5 & 38 \\
\hline
\end{tabular}

Chi-Square test on the relationship between fat consumption frequency and total cholesterol levels obtained $p$-value $=0.150(p>0.05)$, which means no significant relationship between fat consumption frequency and the total cholesterol level of the respondent. The P-value obtained from the Pearson Chi-Square test on the relationship between fibre consumption frequency and total cholesterol levels are $\mathrm{p}=$ 0.631 ( $p>0.05$ ), which means no significant relationship between fibre frequency consumption and the total cholesterol level of the respondent. For the relationship between the frequency of consumption of fast food and total cholesterol levels with the Pearson Chi-Square test, the value of $p=0.150(p>0.05)$ was found, indicating that there was no significant relationship between the frequency of consumption of processed food and the total cholesterol level of the respondents.

The study results on the frequency of carbohydrate consumption among respondents showed that the highest number of respondents frequently consumed carbohydrates as many as 21 people (55.3\%) and rarely consumed carbohydrates as many as 17 people (44.7\%). Of the total carbohydrates, rice is the type of food that is most often consumed by respondents per day, namely as many as 20 people (52.6\%). Indonesian people tend to think of rice as a staple food ingredient that needs to be in a dish arrangement to obtain energy, and usually, rice is an enormous amount in a dish Ortega et al. (1995). However, excessive consumption of carbohydrates can 
cause an increase in triglyceride levels through the breakdown of carbohydrates, namely glucose, which undergoes glycolysis to pyruvate. This process produces acetyl-CoA, which will enter into the oxidative decarboxylation process, which can cause de novo increase in fatty acids (synthesis of precursors. with a more straightforward form). This fatty acid will undergo esterification with triosephosphate produced from the glycolysis process, and the result is an increase in triglycerides, where the excess will be stored in the form of fat under the skin Shehata et al. (2020).

The frequency of protein consumption in the frequent and rare categories was found to be the same, namely 19 people (50\%) in each category. Sources of protein can be obtained from animal protein (meat, fish) and vegetable protein (tofu, tempeh). Meat, fish, and eggs generally contain small amounts of fibre, but tofu and tempeh are types of food that are processed from soybeans, a vegetable protein that has high digestibility due to its relatively high protein and water content. Researchers found that the consumption of tempe and tofu in this study was the most frequently consumed by respondents, namely as many as 14 people $(36.8 \%)$ with a frequency of eating $\geq 1 \mathrm{x}$ / day. It could be because tempeh and tofu have high nutritional value and relative prices. cheap, therefore respondents tend to prefer tempeh and tofu as food substitutes for animal protein Bhaskar (2012); Poggio et al. (2017).

Likewise, the frequency of fat consumption obtained was the same between the frequent and rare categories, namely as many as 19 people (50\%) in each category. The type of fat source with a consumption frequency of $\geq 1 \mathrm{x}$ / day was milk with nine respondents (23.7\%). Judging from the age of the population of study respondents, most respondents were $>40$ years old, where the need for calcium increases with age. It is because calcium plays an essential role in bone maintenance, thus preventing an early decrease in bone strength Poggio et al. (2017).

Not unlike the results of the frequency of fibre consumption, the number of respondents who often and rarely consume fibre is pretty the same, 19 people $(50 \%)$ for the frequent category and 19 people (50\%) for the rare category. Some good sources of fibre for the digestive process are vegetables, fruits, grains and nuts. Consumption of large amounts of vegetables and fruits can prevent constipation, haemorrhoids, diverticulosis, colon cancer, appendicitis, diabetes, coronary heart disease and even obesity because this type of food is affluent in fibre, vitamins and minerals Poggio et al. (2017).

The frequency of fast food consumption also obtained the same results, both in the regular and infrequent consumption frequency categories, namely 19 people $(50 \%)$ in both categories. Fast food is a type of food that is easy to make and easy to consume where. This type of food has low protein levels, vitamins and fibre but is high in simple carbohydrates, trans fatty acids, polyunsaturated fatty salts, and MSG (monosodium glutamate) Ghoochani et al. (2018).Fast food is served briefly and practically fried so that it contains high saturated fat and cholesterol Singh and Mishra (2014). In this study, the type of fast food most frequently consumed by respondents was fried food, with the number of respondents who ate this type of 
food found as many as four people (10.5\%) per day. It is undeniable that fried foods are often consumed in Indonesian people's daily lives. The possibility of this happening is because fried foods can be made easily at home without having to buy them at supermarkets or restaurants, such as fast food and soft drinks.

The results showed that 33 people $(86.8 \%)$ had normal total cholesterol levels, and five people (13.2\%) had high total cholesterol levels. It happens because most of the congregation of the HKBP Sudirman church who are willing to become respondents often eat vegetables and fruit but rarely eat fatty foods. Thus, this study's results are in line with research that states that cholesterol levels can be lowered by consuming dietary fibre, which works by trapping fat in the small intestine and binding bile acids and increasing the excretion of bile acids into feces Ettinger et al. (2017); Fairudz (2015).The researcher also observed that the HKBP church Jalan Jend. Sudirman Jakarta regularly holds outreach related to health problems and routinely checks uric acid, sugar, and total cholesterol in the blood. Therefore, knowledge about various health coverage should have been understood by several respondents regarding a healthy diet-routine total cholesterol checks at the HKBP Jalan Jend. Sudirman Jakarta also helps respondents know the respondent's total cholesterol level so that proper management such as diet control and consumption of anti-hypercholesterolemic drugs as preventive measures can be immediately carried out. Because of this, respondents with normal total cholesterol levels were found to be more than those with high total cholesterol levels. However, in 5 respondents $(13.2 \%)$ who had high total cholesterol levels, when viewed from the age the population was dominated by the age group $>40$ years, were generally the ageing process began to occur in that age group Ramadhani and Probosari (2014). The ageing process is what causes the need for a longer time in transit of food in the gastrointestinal tract of the elderly, then there is more absorption of cholesterol, so it is easy to increase LDL levels, according to research conducted by Potter \& Perry (2010) Ettinger et al. (2017).

This study shows that the Pearson Chi-Square test results on the frequency of carbohydrate consumption with the respondents' total cholesterol level are $\mathrm{p}<0.05$, which means a significant relationship between the frequency of carbohydrate consumption and total cholesterol levels. Carbohydrate consumption affects cholesterol levels, particularly triglyceride levels. High consumption of carbohydrates triggers an increase in triglyceride levels; this is because excess carbohydrates will be broken down through glycolysis and produce glucose, then glucose will be broken down into glycerol three phosphates, the structure of triglycerides. Thus, an increase in the glycerol three phosphate product causes an increase in triglyceride levels Jung and Choi (2017). High intake of carbohydrates can increase triglyceride levels and reduce HDL cholesterol levels Lee and Kim (2018). Types of carbohydrates are divided into 2 , namely simple carbohydrates and complex carbohydrates. Simple carbohydrates are a group of monosaccharides faster and easier to digest in the human body than complex carbohydrates, which are a group of polysaccharides, generally taste taste- 
less (not sweet). The digestion process takes longer. The habit of eating foods containing complex carbohydrates such as starch significantly impacts the digestive system because these carbohydrates generally contain high levels of protein, vitamins, and fibre. In this study, it was found that the frequent consumption of carbohydrate sources, rice type, was the most frequent food consumed by respondents, namely as many as 20 people (52.6\%). Rice, one of them, is a type of food material whose starch content is $>70 \%$ Poggio et al. (2017). The types of rice vary widely. In this study, it was not distinguished what type of rice was consumed by the respondents.

The frequency of excessive consumption of sugary foods and drinks can have a risk of increasing LDL cholesterol by $26 \%$, where LDL cholesterol levels reflect total cholesterol levels Beny et al. (2013); Daoud et al. (2014).The American Heart Association recommends consuming complex carbohydrates instead of simple carbohydrates to reduce cardiovascular disease risk Ohlsson (2010).

The result of $p>0.05$ in the Pearson Chi-Square test on the frequency of protein consumption and the respondent's total cholesterol level means that there is no significant relationship between the frequency of protein consumption and the total cholesterol level of the respondent. The types of protein sources most often consumed by respondents were fish, tempeh and tofu, with the proportion of respondents as many as 14 people (36.8\%). Freshwater fish is rich in carbohydrates and protein, while marine fish is very rich in unsaturated fatty acids (omega-3), where unsaturated fatty acids have a low hypercholesterolemic effect hypocholesterolemic. While the content of niacin and isoflavones in tempeh has an effect that can lower cholesterol Poggio et al. (2017).

Pearson Chi-Square test between the frequency of fat consumption and total cholesterol levels was obtained p>0.05, which means no significant relationship between fat consumption and total cholesterol levels. In this study, milk was the type of fat source most of the respondents consumed every day, as many as nine people $(23.7 \%)$. It is indeed different from the research which states that the fat content in pure, unprocessed milk has a significant effect on increasing total cholesterol levels. However, fermented dairy products such as cheese and bland yoghurt have been shown to reduce total cholesterol levels by as much as 5-9\%. It is because the fermented milk product uses bacterial strains that have a hypocholesterolemic effect. Besides, cheese has a higher calcium content than fat content, which increases the excretion of fat when calcium is absorbed Schwingshackl and Hoffmann (2013). Researchers also observed that, although as many as 9 people $(23.7 \%)$ of respondents consumed milk per day, it was not differentiated whether the milk consumed by respondents was low fat or high (full cream). In general, the types of milk consumed by the elderly are low fat and high calcium milk, so that the proportion of respondents with normal total cholesterol levels is higher than those with Hypercholesterolemia. A meta-analysis study found that consumption of low-fat foods had a significant long-term ( $\geq 12$ months) reduction in LDL cholesterol levels consumption of high-fat foods Waloya et al. (2013). Besides, they often eat vegetables and 
fruit. It shows that there are no respondents who have never eaten vegetables and fruit, where the number of respondents who eat vegetables and fruit is mainly found with a consumption frequency of $\geq 1 \mathrm{x} /$ day, which is as many as 20 people $(52.6 \%)$. ) who eat vegetables and as many as 18 people (47.4\%) eat fruit every day.

Based on the Pearson Chi-Square test results on the frequency of fibre consumption and the respondents' total cholesterol level, it was found that $\mathrm{p}>0.05$, which means that there is no significant relationship between the frequency of fibre consumption and total cholesterol levels. This study's results are consistent with the result that said there is no significant effect between dietary fibre intake and blood cholesterol levels because dietary fibre intake is still low Pang et al. (2010). But this research is different from the other research which states a relationship between vegetable intake and Hypercholesterolemia. In theory, one of the causes of Hypercholesterolemia is the low consumption of fibre Singh and Mishra (2014).About 50\% of carbohydrates derived from plants are cellulose, an essential structure of plant cell walls that increase faeces' volume to facilitate defecation. With sufficient fibre consumption, the absorption of carbohydrates, fats, and proteins is reduced to avoid obesity. Sources of fibre that are proven to reduce cholesterol levels are apples, avocados, and grapes. However, in this study there were 5 respondents $(13.2 \%)$ who experienced hypercholesterolemia, this is likely because these five respondents consumed fiber every month, but not in sufficient levels.

In the Pearson Chi-Square test on the frequency of fast-food consumption with the respondents' total cholesterol level, the p-value is $>0.05$, which means that there is no essential relationship between the frequency of fast food consumption and the total cholesterol level of the respondents. This study's results differ from Monika and Sunita's research in India, showing that excessive consumption of fast food is associated with overweight and obesity because of the fast food content, which is rich in cholesterol, carbohydrates, and salt Ettinger et al. (2017). This excess weight, according to Lediana (2016), greatly affects cholesterol levels Singh and Mishra (2014). In this study, there were four people $(10.5 \%)$ who consumed fried foods every day, and there were 24 people $(63.2 \%)$ who consumed fast food with a frequency of consumption 1-3 times/week. It will affect respondents' total cholesterol levels in the coming years, according to research that showed that consumption of cholesterol as much. This study's result is total cholesterol levels by as much as $0.035 \mathrm{mmol} / \mathrm{L}$ and decreases HDL levels by as much as $0.014 \mathrm{mmol} / \mathrm{L}$ [42]. Researchers see that although there are quite some respondents who have normal total cholesterol levels, this does not rule out that in the future, Hypercholesterolemia may occur if the frequency of consumption of fast food is not controlled.

\section{CONCLUSION}

After researching eating frequency patterns with total cholesterol levels of respondents at the HKBP Sudirman church, 2018, with 38 respondents, the researchers 
drew the following conclusions: a) Based on the study results, 33 respondents had normal total cholesterol levels. (86.8\%) Furthermore, those with Hypercholesterolemia were five people (13.2\%); b) The type of food most often consumed by respondents with a consumption frequency of $\geq 1 \mathrm{x} /$ day from carbohydrate intake was rice, as many as 20 people (52.6\%), followed by protein intake were fish, tempeh and tofu as many as 14 people (36.8\%). The fat intake is milk as much as nine people (23.7\%), then from the fibre intake is vegetables as much as 20 people $(52.6 \%)$ and from fast food is fried food by four people (10.5\%); and c) Based on the results of the Pearson Chi-Square test, it was found that there was a significant relationship between the frequency of carbohydrate consumption and the total cholesterol level of the respondents. However, this study did not find a significant relationship between the frequency of protein consumption, fat, fibre, and fast food with the respondents' total cholesterol level.

\section{REFERENCES}

Ali, K. (2006). Healthy Food Solutions. In Healthy Food Solutions, PT. Rajagrafindo Persada. Jakarta.

Beny, S., Chasani, A., Santoso, S., \& S. (2013). Differences in lipid profiles in patients with acute myocardial infarction and non-acute myocardial infarction (Doctoral dissertation, Diponegoro University). Differences in lipid profiles in patients with acute myocardial infarction and non-acute myocardial infarction (Doctoral dissertation.

Bhaskar, R. (2012). Junk food: Impact on health. Journal of Drug Delivery and Therapeutics, $2(3)$.

Cahanar, P., \& Suhanda, I. (2006). Eat healthy, live healthy. Eat healthy, live healthy.

Cummins, S., Flint, E., \& Matthews, S. A. (2014). New Neighborhood Grocery Store Increased Awareness Of Food Access But Did Not Alter Dietary Habits Or Obesity. Health Affairs, 33(2), 283-291. Retrieved from https://dx.doi.org/10.1377/hlthaff.2013.0512

Daoud, E., Scheede-Bergdahl, C., \& Bergdahl, A. (2014). Effects of Dietary Macronutrients on Plasma Lipid Levels and the Consequence for Cardiovascular Disease. Journal of Cardiovascular Development and Disease, 1(3), 201-213. Retrieved from https://dx.doi.org/ 10.3390/jcdd1030201 10.3390/jcdd1030201

Ettinger, S. J., Feldman, E. C., \& Cote, E. (2017). Textbook of Veterinary Internal MedicineeBook. Elsevier health sciences. In and others (Ed.), . Elsevier health sciences.

Fairudz, A. (2015). The effect of dietary fiber on cholesterol levels in overweight sufferers. Jurnal Majority, 4(8), 121-126.

Fatmah, D., \& Skm, M. S. (2010). Elderly nutrition. Jakarta Erlangga.

Garrett, R. H., \& Grisham, C. M. (2010). Glycolysis. Biochemistry,. Glycolysis. Biochemistry, 535562.

Ghoochani, O. M., Torabi, R., Hojjati, M., Ghanian, M., \& Kitterlin, M. (2018). Factors influencing Iranian consumers' attitudes toward fast-food consumption. British Food Journal, 120(2), 409-423. Retrieved from https://dx.doi.org/10.1108/bfj-12-2016-0612 10.1108/bfj-12-2016-0612

Indrati, R., \& Gardjito, M. (2014). Food consumption education: Processing and safety aspects. In Food consumption education: Processing and safety aspects. Jakarta, Kencana.

Jung, C. H., \& Choi, K. M. (2017). Impact of high-carbohydrate diet on metabolic parameters 
in patients with type 2 diabetes. Nutrients, 9(4), 322-322.

Lee, J., \& Kim, J. (2018). Association between dietary pattern and incidence of cholesterolemia in Korean adults: the Korean Genome and Epidemiology Study. Nutrients, 10(1), 53-53.

Malik, M. A. (2011). Description of Total Blood Cholesterol Levels in Class. Sam Ratulangi University with a Body Mass Index of 18.5-22.9 kg / m2. eBiomedik, 1-1.

Murray, R. K., Granner, D. K., Mayes, P. A., \& Rodwell, V. W. (2003). Biochemistry Harper edition 25. Book Medical Publishers EGC, 236-244.

Ohlsson, L. (2010). Dairy products and plasma cholesterol levels (Vol. 54). SNF Swedish Nutrition Foundation. Retrieved from https://dx.doi.org/10.3402/fnr.v54i0.5124 10.3402/ fnr.v54i0.5124

Ortega, R. M., Requejo, A. M., Andrés, P., Löpez-Sobaler, A. M., Redondo, R., \& Gonz, M. (1995). Relationship between diet composition and body mass index in a group of Spanish adolescents. British Journal of Nutrition, 74(6), 765-773.

Pang, S. J., Jia, S. S., Man, Q. Q., Song, S., Li, Y. Q., Song, P. K., Zhang, .., \& J. (2010). Dietary cholesterol in the elderly Chinese population: an analysis of CNHS. Nutrients, 9(9), 934934.

Poggio, R., Elorriaga, N., Gutierrez, L., Irazola, V., Rubinstein, A., \& Danaei, G. (2017). Associations between dietary patterns and serum lipids, apo and C-reactive protein in an adult population: evidence from a multi-city cohort in South America. British Journal of Nutrition, 117(4), 548-555. Retrieved from https://dx.doi.org/10.1017/ s0007114517000514 10.1017/s0007114517000514

Ramadhani, A., \& Probosari, E. (2014). Differences in Triglyceride Levels Before and After Giving Jicama Extract (Pachyrrhizus erosus) in Women (Doctoral dissertation, Diponegoro University). Differences in Triglyceride Levels Before and After Giving Jicama Extract (Pachyrrhizus erosus) in Women (Doctoral dissertation.

Rastogi, S. C., Rastogi, P., \& Mendiratta, N. (2008). Genomics Proteomics And Drug Discovery. Bioinformatics Methods And Applications: Genomics Proteomics And Drug Discovery 3Rd Ed. PHI Learning Pvt. Ltd.

Ri, K. (2013). Health research and development agency. Health research and development agency. Basic health research.

Schwingshackl, L., \& Hoffmann, G. (2013). Comparison of Effects of Long-Term Low-Fat vs High-Fat Diets on Blood Lipid Levels in Overweight or Obese Patients: A Systematic Review and Meta-Analysis. Journal of the Academy of Nutrition and Dietetics, 113(12), 1640-1661. Retrieved from https://dx.doi.org/10.1016/j.jand.2013.07.010 10.1016/ j.jand.2013.07.010

Shehata, S. A., Abdeldaym, E. A., Ali, M. R., Mohamed, R. M., Bob, R. I., \& Abdelgawad, K. F. (2020). Effect of Some Citrus Essential Oils on Post-Harvest Shelf Life and Physicochemical Quality of Strawberries during Cold Storage. Agronomy, 10(10), 14661466. Retrieved from https://dx.doi.org/10.3390/agronomy10101466 10.3390/ agronomy10101466

Singh, M., \& Mishra, S. (2014). Fast food consumption pattern and obesity among school going (9-13 year) in Lucknow District. International Journal of Science and Research, 3(6), 1672-1674.

Sjöberg, B. (2016). Studies on cholesterol and bile acid metabolism in relation to plasma lipoproteins. In Studies on cholesterol and bile acid metabolism in relation to plasma lipoproteins. Huddinge.

Supariasa, I. D., Bakri, B., \& Fajar, I. (2012). Assessment of Nutritional Status. Jakarta: EGC. Journal of the Relationship between Diet and Pre-School Nutritional Status in Paud Tunas 
Mulia Claket, 1(2), 69-76.

US Department of Health and Human Services. (2005). High Blood Cholesterol: What You Need To Know. National Heart, Lung, and Blood Institute Health Information Center website. Retrieved from http://www.nhlbi.nih.gov/health/public/heart/chol/wyntk

Waloya, T., Rimbawan, R., \& Andarwulan, N. (2013). HUBUNGAN ANTARA KONSUMSI PANGAN DAN AKTIVITAS FISIK DENGAN KADAR KOLESTEROL DARAH PRIA DAN WANITA DEWASA DI BOGOR. Jurnal Gizi dan Pangan, 8(1), 9-9. Retrieved from https://dx.doi .org/10.25182/jgp.2013.8.1.9-16 10.25182/jgp.2013.8.1.9-16

Yoeantafara, A., \& Martini, S. (2017). Effect of Diet on Total Cholesterol Levels. Jurnal Mkmi, 13(4), 304-309. 